\title{
ACCELERATOR MASS SPECTROMETRY ANALYSIS OF NON-SOLUBLE CARBON IN AEROSOL PARTICLES FROM HIGH ALPINE SNOW (MT. SONNBLICH, AUSTRIA)
}

\author{
Roland H Weissenbök $\mathrm{k}^{1,2} \bullet$ Lloyd A Currie ${ }^{3}$ Christina Gröllert ${ }^{4} \bullet$ Walter Kutschera ${ }^{1} \bullet$ \\ Julie Marolf ${ }^{3} \bullet$ Alfred Priller $^{1} \bullet$ Hans Puxbaum $^{4} \bullet$ Werner Rom $^{1} \bullet$ Peter Steier $^{1}$
}

\begin{abstract}
With an elaborate accelerator mass spectrometry (AMS) technique radiocarbon measurements have been performed with aerosol carbon filtered from high alpine snow samples gathered consecutively at the high-altitude research station Sonnblick (3106 m, Eastern Alps, Austria) during a snow storm in April 1997. The concentration of the water-insoluble carbonaceous material in the molten snow was on the average $310 \mu \mathrm{g} \mathrm{C} / \mathrm{L}$ and the total sample amounts for analysis were in the range of $35 \mu \mathrm{g}$ to $60 \mu \mathrm{g}$ C. Using a special background correction procedure tested on similar amounts of an urban particulate standard sample the accuracy of the corrected and normalized ${ }^{14} \mathrm{C} /{ }^{12} \mathrm{C}$ isotopic ratios of the snow aerosol samples was in the order of $4 \%$ to $14 \%$ of the measured ratios. The water-insoluble carbonaceous material of five samples from Mt. Sonnblick exhibited a weighted mean of $74 \mathrm{pMC}$ (percent Modern Carbon) with a range of $64 \mathrm{pMC}$ to 88 pMC. Thus, it appears that about $64 \%$ of non-soluble carbon in high alpine snow from Sonnblick was of biogenic origin. The temporal variations of the ${ }^{14} \mathrm{C} /{ }^{12} \mathrm{C}$ isotopic ratios of the snow aerosol samples were statistically significant, suggesting alterations in the contribution of specific aerosol sources.
\end{abstract}

\section{INTRODUCTION}

Since the ${ }^{14} \mathrm{C} /{ }^{12} \mathrm{C}$ ratio gives a unique and absolute measure of the contemporary/fossil source ratio transient atmospheric phenomena and specific source contributions can be explored (Currie et al. 1996, 1998). Especially aerosol samples of remote territories, e.g. the Arctic and the Antarctic region, and of secluded mountain ranges, e.g. the major parts of the Alps, are capable of giving new information on long-range transport phenomena. However, the very low concentration of carbonaceous aerosols makes these measurements a challenge, even for the highly sensitive method of accelerator mass spectrometry (AMS). For the extension to carbon masses less than $100 \mu \mathrm{g}$, a special micro-technique for sample preparation (Verkouteren et al. 1997), combined with modifications in the operating conditions of the Vienna Environmental Research Accelerator (VERA) (Kutschera et al 1997; Priller et al. 1997; Weissenbök et al. 1998), and the data evaluation process were necessary. The reproducibility is mainly limited by counting statistics and variability of "blank" corrections. Here we use this special small sample AMS technique for investigations of the filterable carbonaceous material in snow from a high alpine site in Central Europe.

\section{Carbonaceous Aerosols in Air and Snow}

The total carbon (TC) of atmospheric aerosols contain carbonate carbon (CC), elemental carbon (EC) and organic carbon (OC) (Saxena and Hildemann 1996). Recent data from EC/TC measurements of Mt. Sonnblick aerosol show a ratio of 0.085 to 0.19 (Hitzenberger et al. 1999). However, only $50 \%$ of the TC from aerosols in rural samples is water-insoluble (Saxena and Hildemann 1996). The filterable portion of the carbonaceous aerosol in snow includes the EC fraction and just a certain part of the OC fraction (Chylek and Srivastava 1987; Saxena and Hildemann 1996). While EC sources are known (biomass and fossil fuel combustion) (Cooke and Wilson 1996), the sources for insoluble OC are not well defined (Saxena and Hildemann 1996). Recently, biopolymers were iden-

\footnotetext{
${ }^{1}$ Vienna Environmental Research Accelerator, University of Vienna, Vienna, Austria

${ }^{2}$ Present affiliation: Atomic Institute of the Austrian Universities, Vienna University of Technology, Austria.

E-mail: rweissen@ati.ac.at.

${ }^{3}$ Chemical Science and Technology Lab, National Institute of Standards and Technology, Gaithersburg, Maryland, USA

${ }^{4}$ Institute for Analytical Chemistry, Vienna University of Technology, Vienna, Austria
} 
tified as potentially water-insoluble organic carbonaceous material. Kunit and Puxbaum reported about the occurrence of cellulose, tracer for plant debris, in atmospheric aerosols (Kunit and Puxbaum 1996). Fossil carbon is expected to have 0 pMC, whereas recent biogenic material has about 115 pMC (Levin et al. 1995).

\section{SAMPLING SITE}

Mt. Sonnblick is situated in the main ridge of the Austrian Alps (Hohe Tauern, $12^{\circ} 57^{\prime} \mathrm{E}, 47^{\circ} 03^{\prime} \mathrm{N}$ ) and is among the highest peaks in the area $(3106 \mathrm{~m})$. A meteorological observation station on the summit of Mt. Sonnblick (see Figure 1) was established in 1886 and is accessible year-round. It is surrounded by large glacier fields to the east and south, and has the ideal characteristics of a high alpine background station since there are in general few tourists and essentially no local sources of carbonaceous aerosols.

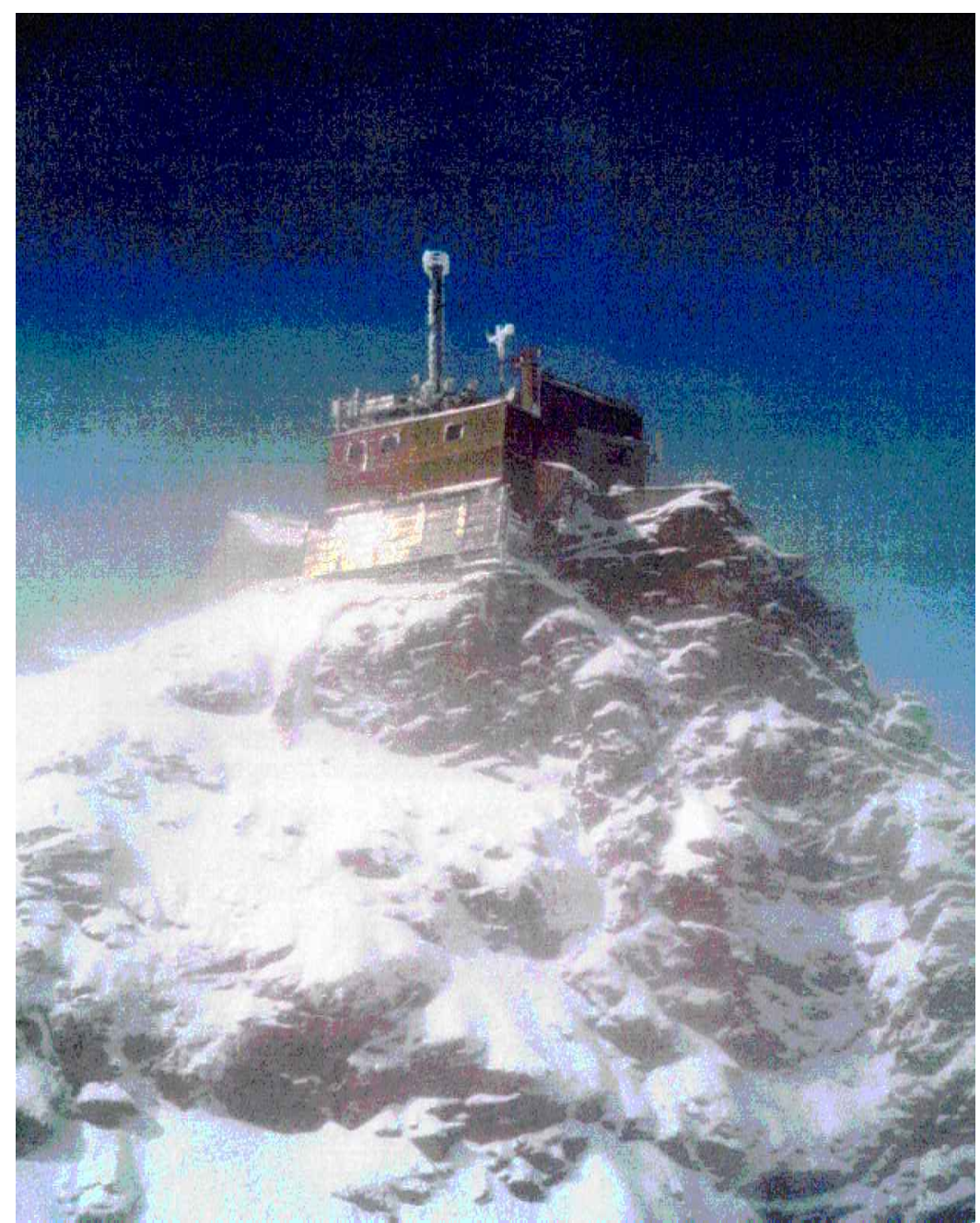

Figure 1 The high altitude research station Sonnblick (3106 m) in the Austrian Alps 


\section{SNOW SAMPLING}

During a strong snow storm in April 1997 fresh fallen snow layers of about $10 \mathrm{~cm}$ thickness were collected at a platform on the high altitude research station (Table 1). The snow samples were stored in pre-cooled glass bottles ( $1 \mathrm{~L})$ and kept frozen until the time of the chemical treatment at the National Institute of Standards and Technology (NIST). For quality control purposes, two samples (S6, S9) were each divided into sub-samples at NIST.

The amount of water-insoluble carbon from the snow samples was about $310 \mu \mathrm{g} / \mathrm{L}$. Recently, Lavanchy et al. (1999) similarly gathered $380 \mu \mathrm{g} / \mathrm{L}$ from snow from Colle Gnifetti (Monte Rosa, Switzerland, $4452 \mathrm{~m})$.

Table 1 Data of the carbonaceous snow sample collected at the high altitude research station Sonnblick

\begin{tabular}{|c|c|c|c|c|c|c|c|}
\hline $\begin{array}{l}\text { Sample } \\
\text { ID }^{\mathrm{a}}\end{array}$ & Start date & $\begin{array}{l}\text { Start } \\
\text { time } \\
\text { (UTC) }\end{array}$ & End date & $\begin{array}{l}\text { End } \\
\text { time } \\
\text { (UTC) }\end{array}$ & $\begin{array}{l}\text { Volume of } \\
\text { melted } \\
\text { snow }(\mathrm{mL})\end{array}$ & $\begin{array}{c}\text { Mass of } \\
\text { insoluble } \\
\text { carbon } \\
\text { fraction }(\mu \mathrm{g})\end{array}$ & $\begin{array}{c}\text { Carbon mass } \\
\text { per volume } \\
\text { snow }(\mu \mathrm{g} / \mathrm{L})\end{array}$ \\
\hline S6a & 29-04-1997 & 09:00 & 29-04-1997 & $12: 00$ & 109 & 38.1 & 350 \\
\hline S6b & & & & & 91 & 37.3 & 410 \\
\hline S7 & 29-04-1997 & $12: 00$ & 29-04-1997 & 21:00 & 200 & 58.6 & 293 \\
\hline S8 & 29-04-1997 & 21:00 & 30-04-1997 & $05: 15$ & 190 & 37.7 & 198 \\
\hline S9a & 30-04-1997 & $05: 15$ & 30-04-1997 & $18: 00$ & 109 & 34.7 & 318 \\
\hline $\mathrm{s} 9 \mathrm{~b}$ & & & & & 173.5 & 61.3 & 353 \\
\hline $\mathrm{S} 10$ & 30-04-1997 & 18:00 & 30-04-1997 & $21: 10$ & 178 & 45.9 & 258 \\
\hline
\end{tabular}

${ }^{\text {a }}$ Snow samples S6 and S9 were divided for quality purposes

\section{SAMPLE TREATMENT AND TARGET PREPARATION ${ }^{5}$}

The snow samples were melted in a room-temperature bath and the resulting solutions were filtered through pre-fired Pallflex ${ }^{\circledR}$, high purity quartz filters (Pall Gelman Laboratory ${ }^{\mathrm{TM}}$, type: Tissuquartz 2500 QAT-UP). These had a typical aerosol retention of $99.999 \%$ for $0.5 \mu \mathrm{m}$ particles and $99.99 \%$ for $0.3-0.05 \mu \mathrm{m}$ particles respectively at standard test conditions. The retention is specified by the American Society of Testing and Materials (ASTM) designation number D-2986-71 for diocthyl phthalate smoke particles and an air flow of $32 \mathrm{~L} / \mathrm{min}$ through a $100 \mathrm{~cm}^{2}$ filter area. Subsequently, the filters were dried at $110^{\circ} \mathrm{C}$ for $3 \mathrm{hr}$. Carbonates were then removed by exposing the filters to $\mathrm{HCl}$ vapors for 5-7 hr. After that, the filters were placed into a container with $\mathrm{NaOH}$ in order to attempt neutralizing the filter surface. Finally, the carbonaceous residue on the filter was combusted in a preheated quartz tube with addition of $200 \mathrm{mg} \mathrm{CuO}$. Halides were removed with $40 \mathrm{mg}$ silver wire. The individual sample $\mathrm{CO}_{2}$ was then transferred to the evacuated graphitization system (see Figure 2) and trapped with liquid nitrogen. After pumping off residual gases the $\mathrm{CO}_{2}$ mass was quantified by manometry at room-temperature. According to Verkouteren et al. (1997), the $\mathrm{CO}_{2}$ was then cryotransferred to an evacuated quartz tube, containing $100 \mathrm{mg}$ Mn-chips and $2 \mathrm{mg} \mathrm{Fe}$-wool. The tube was then flame-sealed. The $\mathrm{CO}_{2}$ was first reduced to $\mathrm{CO}$ by the Mn-chips and then catalytically to

\footnotetext{
${ }^{5}$ Work in this section that was performed at the National Institute of Standards and Technology is not subjected to copyright in the USA. Commercial materials are identified in this paper to foster understanding. Such identification does not imply recommendation or endorsement by the National Institute of Standards and Technology, nor does it imply that the materials identified are necessarily the best available for the purpose.
} 
graphite on the Fe-wool $\left(24 \mathrm{hr}\right.$ at $\left.600{ }^{\circ} \mathrm{C}\right)$. Finally, the sample Fe-C matrix was magnetically separated from the Mn-chips, the tube was filled with ultra high purity helium and the matrix was sintered at $1575{ }^{\circ} \mathrm{C}$. The result was a solid bead of $0.5 \mathrm{~mm}$ to $0.9 \mathrm{~mm}$ diameter.

For quality purposes some "artificial" snow processing samples were generated by filtering distilled water through two carbon reference materials: SRM 1649a, the Washington, DC Urban Dust (aerosol) standard reference material (aerosol reference samples, Table 2), and SP-2, a commercial graphite material that is used as a "dead" ${ }^{14} \mathrm{C}$ reference material by NIST (dead reference samples, Table 2). The filtering process, followed by closed-tube combustion of the carbon retained on the high purity quartz filter, is labeled "total chemistry". When the same two reference materials on quartz fiber filters were submitted to closed-tube combustion, without the initial filtering step, the process was deemed "combustion". A third preparation method used to generate "bulb" samples of HOxI (SRM 4990B) $\left({ }^{14} \mathrm{C}\right.$ dating reference sample, Table 2) was designed to minimize carbon blanks associated with sample processing. It utilized direct combustion of HOxI in amounts ( $>1 \mathrm{mg}$ carbon equivalent) quite large compared to typical combustion blanks. Finally, the combustion and total chemistry blanks were prepared without the presence of SP-2 or SRM 1649a (blank samples, Table 2).

Following combustion to $\mathrm{CO}_{2}$, samples were prepared as Fe-C bead targets which were fixed into a custom-made Al target holder and then mounted into the 40-position Al-target wheel of the negative ion sputter source of VERA. The sample labeled "HPG no chemistry" in Table 2 was an exception, in that case the carbonaceous material was used directly as an AMS target without any chemical processing. HPG is a VERA high purity graphite reference material that is ${ }^{14} \mathrm{C}$-free ("dead"). Note that all uncertainties quoted are combined standard uncertainties $\left(\mathrm{u}_{\mathrm{c}}\right)$ that are essentially due to counting statistics and variations of the blank carbon mass of individual samples.

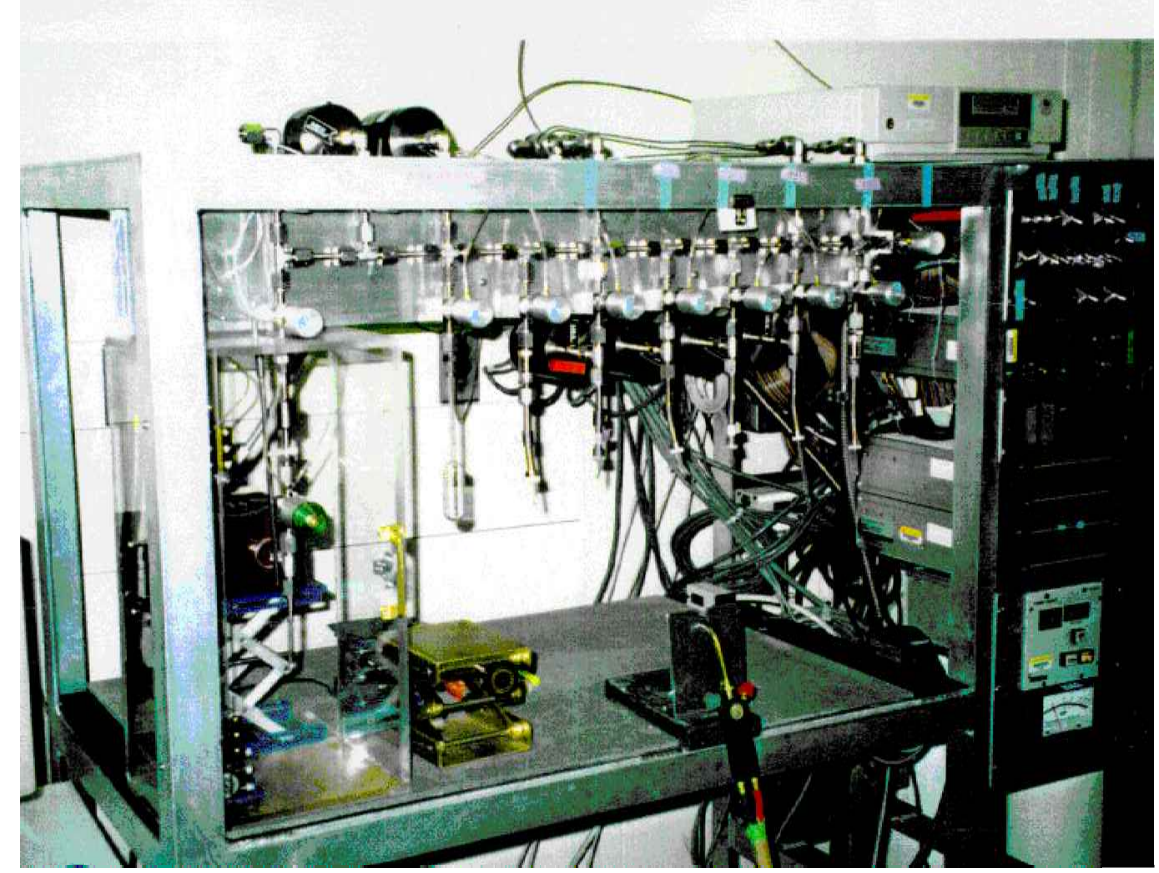

Figure 2 Photograph of the graphitization system at NIST 
Table 2 Results of the carbonaceous samples measured at VERA in November $1998^{\mathrm{a}}$

\begin{tabular}{|c|c|c|c|c|}
\hline Sample material & $\begin{array}{c}\mathrm{m}_{\mathrm{s}}, \mathrm{m}_{\mathrm{b}}^{\mathrm{b}} \\
(\mu \mathrm{g})\end{array}$ & $\begin{array}{l}f_{s}, f_{b}{ }^{c} \\
\left(10^{-12}\right)\end{array}$ & $\begin{array}{c}\mathrm{f}_{0, \mathrm{~s}}{ }^{\mathrm{d}} \\
\left(10^{-12}\right)\end{array}$ & $\begin{array}{c}{ }^{14} \mathrm{C}_{\mathrm{s}}{ }^{\mathrm{e}} \\
(\mathrm{pMC})^{\mathrm{f}}\end{array}$ \\
\hline \multicolumn{5}{|l|}{ "Dead" reference samples } \\
\hline SP2-Combusted & 23.4 & $0.253 \pm 0.13$ & - & - \\
\hline SP2-Combusted & 68.9 & $0.0458 \pm 0.0023$ & - & - \\
\hline SP2-Total chemistry & 18.0 & $0.87 \pm 0.11$ & - & - \\
\hline SP2-Total chemistry & 51.7 & $0.201 \pm 0.050$ & - & - \\
\hline SP2-Total chemistry & 91.4 & $0.1306 \pm 0.0034$ & - & - \\
\hline HPG-No Chemistry & - & $0.00098 \pm 0.00033$ & - & $0.11 \pm 0.04$ \\
\hline \multicolumn{5}{|l|}{ “Blank” samples } \\
\hline Combustion blank & 5.8 & $1.25 \pm 0.20$ & - & - \\
\hline Total chemistry blank & 13.8 & $0.983 \pm 0.023$ & - & - \\
\hline \multicolumn{5}{|l|}{${ }^{14} \mathrm{C}$ dating reference samples } \\
\hline HOxI-Bulb & 42.0 & $0.9554 \pm 0.0067$ & - & Ref. material \\
\hline \multicolumn{5}{|l|}{ Aerosol reference samples } \\
\hline SRM 1649a-Combusted & 27.5 & $0.603 \pm 0.010$ & $0.481 \pm 0.068$ & $52.3 \pm 7.4$ \\
\hline SRM 1649a-Combusted & 84.5 & $0.5196 \pm 0.0092$ & $0.480 \pm 0.022$ & $52.2 \pm 2.4$ \\
\hline SRM 1649a-Total chemistry & 33.4 & $0.6383 \pm 0.0079$ & $0.416 \pm 0.067$ & $45.3 \pm 7.3$ \\
\hline SRM 1649a-Total chemistry & 71.4 & $0.522 \pm 0.011$ & $0.418 \pm 0.027$ & $45.5 \pm 3.0$ \\
\hline SRM 1649a-Total chemistry & 192.0 & $0.4741 \pm 0.0062$ & $0.437 \pm 0.010$ & $47.6 \pm 1.1$ \\
\hline \multicolumn{5}{|l|}{ Sonnblick snow samples } \\
\hline S6-Total chemistryg & 37.7 & $0.798 \pm 0.018$ & $0.699 \pm 0.040$ & $76.1 \pm 4.4$ \\
\hline S7-Total chemistry & 58.6 & $0.678 \pm 0.011$ & $0.590 \pm 0.025$ & $64.2 \pm 2.8$ \\
\hline S8-Total chemistry & 37.7 & $0.869 \pm 0.070$ & $0.808 \pm 0.109$ & $87.9 \pm 11.9$ \\
\hline S9-Total chemistry & 48.0 & $0.859 \pm 0.025$ & $0.812 \pm 0.037$ & $88.4 \pm 4.1$ \\
\hline S10-Total chemistry & 45.9 & $0.773 \pm 0.014$ & $0.689 \pm 0.030$ & $75.0 \pm 3.3$ \\
\hline $\begin{array}{l}\text { a All isotopic uncertainties (last } 3 \mathrm{c} \\
\text { b Carbon masses measured by man } \\
{ }^{\mathrm{c}} \text { Isotopic ratio }{ }^{14} \mathrm{C} /{ }^{12} \mathrm{C} \text { of the indiv } \\
\text { d Isotopic ratio }{ }^{14} \mathrm{C} /{ }^{12} \mathrm{C} \text { of the indiv } \\
{ }^{\mathrm{e}} \text { Relative }{ }^{14} \mathrm{C} \text { content of an individ } \\
{ }^{\mathrm{f}} \mathrm{pMC}=\text { percent Modern Carbon } \\
\mathrm{g} \text {. }\end{array}$ & $\begin{array}{l}\text { ) are coml } \\
\text { ample s or } \\
\text { ample s (b } \\
\text { aple s (bac } \\
\text { as } 100 \text { for }\end{array}$ & $\begin{array}{l}\text { d standard uncertainties } \\
\text { nk b (normalized to }-25 \\
\text { ground corrected) } \\
\text { ound corrected) } \\
50 \mathrm{AD} \text { ) }\end{array}$ & & \\
\hline
\end{tabular}

\section{${ }^{14} \mathrm{C}$ MEASUREMENT}

VERA (see Figure 3) is designed for fast sequential injection of the carbon isotopes ${ }^{12} \mathrm{C}^{-},{ }^{13} \mathrm{C}^{-}$and ${ }^{14} \mathrm{C}^{-}$. This is achieved by applying different voltages to the insulated vacuum chamber ("bouncer") of the injection magnet (Priller et al. 1997). The 3-MV Pelletron tandem accelerator was operated with $2.7 \mathrm{MV}$ terminal voltage and Ar-gas stripping. At the high-energy analyzing magnet, ${ }^{12} \mathrm{C}^{3+}$ and ${ }^{13} \mathrm{C}^{3+}$ currents were measured in the respective offset Faraday cups. Typical ${ }^{12} \mathrm{C}^{3+}$ currents were in the range of $6 \mathrm{nA}$ to $1800 \mathrm{nA}$ compared to $9 \mu \mathrm{A}$ to $12 \mu \mathrm{A}$ for $\mathrm{mg}$-sized archaeological samples (see also Rom et al. 1998; Wild et al. 1998). These low currents required an adjustment of the timing of the sequential injection system, since the gain and integration times of the Faraday cup amplifiers had to be enhanced for a reliable current measurement. For a complete isotope cycle ${ }^{12} \mathrm{C}^{-}$was therefore injected for $3 \mathrm{~ms},{ }^{13} \mathrm{C}^{-}$for $126 \mathrm{~ms}$ and ${ }^{14} \mathrm{C}^{-}$for $1000 \mathrm{~ms}$. The ${ }^{14} \mathrm{C}^{3+}$ ions were counted with a solid-state surface barrier detector. Each run consisted of 180 cycles. 

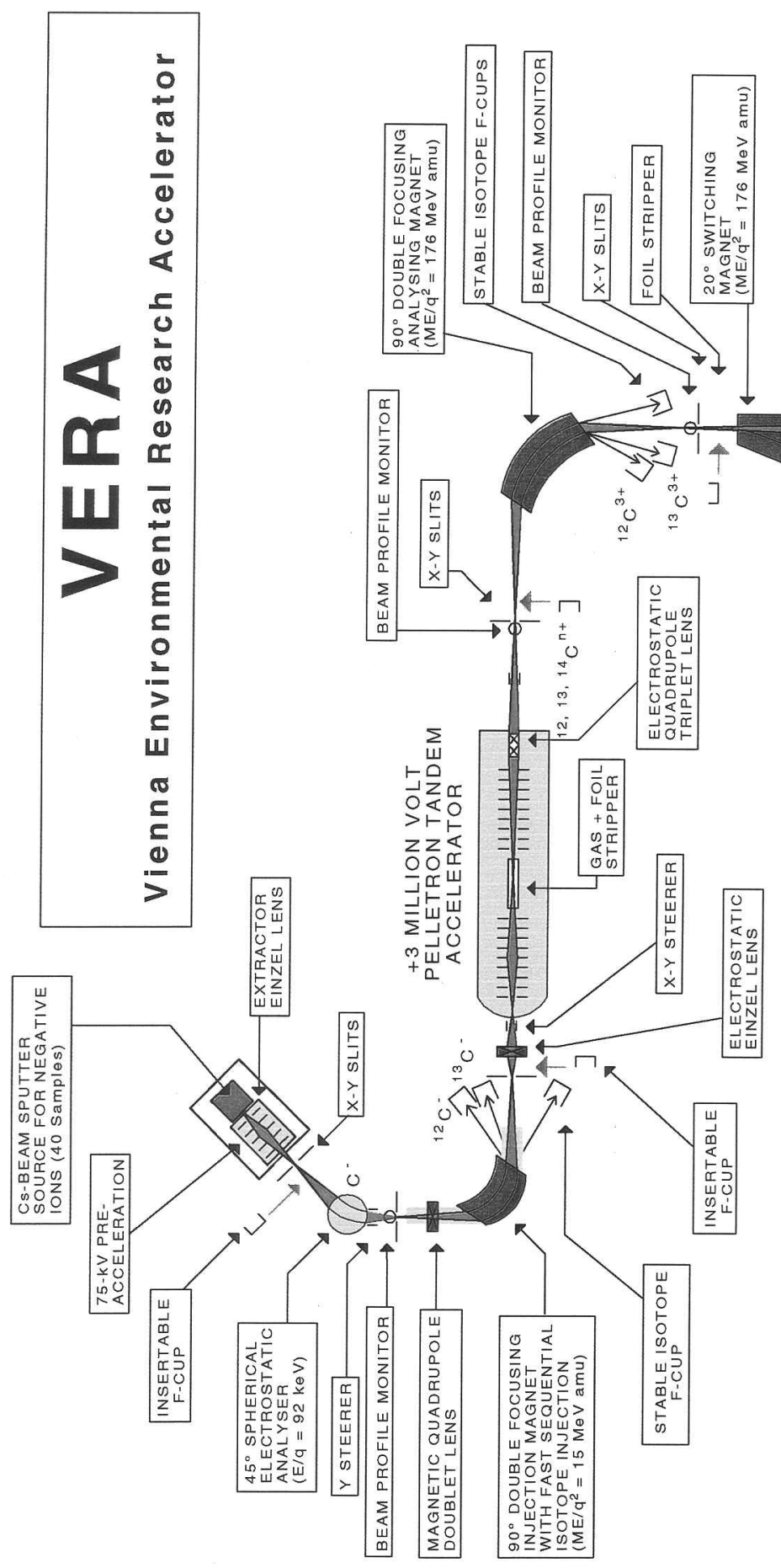

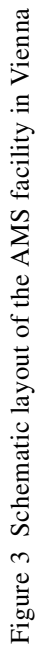




\section{DATA ANALYSIS, RESULTS AND DISCUSSION}

HOxI was used as ${ }^{14} \mathrm{C}$ reference material for both $\delta^{13} \mathrm{C}$ and ${ }^{14} \mathrm{C}$ content determinations. Whenever more than one target per sample was available, the weighted mean calculated from the individual targets were used. The ${ }^{14} \mathrm{C} /{ }^{12} \mathrm{C}$ isotopic ratio $\mathrm{f}$ of all samples $\mathrm{S}$ (except $\mathrm{HOxI}$ ) were normalized to $\delta^{13} \mathrm{C}=-25 \%$ according to (Stuiver and Polach et al. 1977)

$$
\mathrm{f}_{\mathrm{s}}=\left(\frac{{ }^{14} \mathrm{C}}{{ }^{12} \mathrm{C}}\right)_{\mathrm{S},-25}=\left(\frac{{ }^{14} \mathrm{C}}{{ }^{12} \mathrm{C}}\right)_{\mathrm{S}, \text { meas }}\left[1-\frac{2\left(25+\mathrm{d}^{13} \mathrm{C}_{\mathrm{S}}\right)}{1000}\right]
$$

Subsequently, the individually normalized ${ }^{14} \mathrm{C} /{ }^{12} \mathrm{C}$ ratios were background corrected. The blank corrected ("true") isotopic ratio $\mathrm{f}_{0, \mathrm{~s}}$ of the individual sample was determined by

$$
f_{0, s}=\frac{m_{s} f_{s}-m_{b} f_{b}}{m_{s}-m_{b}}
$$

assuming that the measured carbon mass $\mathrm{m}_{\mathrm{s}}$ was the sum of the "true" carbon mass $\mathrm{m}_{0}$ and the blank carbon mass $\mathrm{m}_{\mathrm{b}}$ (see also Verkouteren et al. 1997). The latter is essentially independent of $\mathrm{m}_{\mathrm{s}}$ (Weissenbök et al. 1998) and was derived directly (i.e. without adding any sample carbon) by measuring the pressure of the residual $\mathrm{CO}_{2}$ from both combustion only and total chemistry (Table 2), but also indirectly by using $\mathrm{f}_{\mathrm{s}}$ and $\mathrm{m}_{\mathrm{s}}$ from the nominally ${ }^{14} \mathrm{C}$-free SP-2 samples $\left(\mathrm{f}_{0, \mathrm{~s}}=0\right)$ and $\mathrm{f}_{\mathrm{b}}$ from the corresponding "blank" samples. The mean total chemistry blank was $13.1 \pm 2.3 \mu \mathrm{g}$ and the mean combustion blank was $4.35 \pm 1.67 \mu \mathrm{g}$. These values were used for background correction of the aerosol "standard" samples and the Sonnblick snow samples (Table 2). The above uncertainties are arithmetic standard deviations from the mean. The carbon contamination of the combustion blank mainly originated from the $\mathrm{CuO}$ used for the combustion to $\mathrm{CO}_{2}$ (Weissenbök et al. 1998).

The relative ${ }^{14} \mathrm{C}$ content ${ }^{14} \mathrm{C}_{\mathrm{s}}$ of the individual samples given in $\mathrm{pMC}$ was determined by

$$
{ }^{14} \mathrm{C}_{\mathrm{s}}=100 \frac{\mathrm{f}_{0, \mathrm{~s}}}{0.95 \mathrm{f}_{0, \mathrm{HOxI}}}
$$

The individual relative ${ }^{14} \mathrm{C}$ contents of the "combusted" and "total chemistry" SRM 1649a reference samples were in the range of $45.3 \mathrm{pMC}$ to $52.3 \mathrm{pMC}$ (Table 2). Although the weighted means of the three total chemistry samples $(47.3 \pm 1.0 \mathrm{pMC})$ were lower than those of the two combustion samples $\left(52.2 \pm 2.3 \mathrm{pMC}\right.$ ), their $95 \%$ confidence intervals (CI) overlapped. ${ }^{6}$ (In fact, the entire set of 5 was self-consistent within the stated uncertainties, based on a Student $t$ test: $t / d f=0.234, p=0.53$.) On the other hand, only the weighted mean of the two combustion samples was consistent with the NIST reference value $(50.9 \pm 1.3 \mathrm{pMC})$. Carbonate removal process appears to be the main reason for this discrepancy.

${ }^{14} \mathrm{C}_{\mathrm{s}}$ of the filterable aerosol from snow samples collected at Mt. Sonnblick in April 1997 varied between 64 and 88 pMC (see Figure 4) with a weighted mean of $73.7 \pm 1.7$ pMC. This result indicates that about $64 \%$ of filterable carbon in high alpine snow from Sonnblick was of biogenic origin. The

\footnotetext{
${ }^{6} \mathrm{All}{ }^{14} \mathrm{C}$ uncertainties represent combined standard uncertainties, representing counting statistics and variations of the carbon blank mass. Uncertainties in volumes in Table 1 and masses in Tables 1 and 2 were less than one unit in the last digit.
} 
overall variations were statistically significant $\left(\chi^{2} / \mathrm{df}=6.7, \mathrm{p}<0.0001\right)$, suggesting variations in the contribution of specific aerosol sources. In order to assess the variability of the data an attempt was made to locate the possible origin of the aerosols. We calculated $96 \mathrm{hr}$ backward trajectories of air masses that reached Mt. Sonnblick at 12:00 and 0:00 UTC (Universal Time Coordinate), respectively, during the time of interest (see also Rom et al., 1999). In all cases, the station backward trajectories showed contact with the earth's surface $24-36 \mathrm{hr}$ earlier, so that the air masses transported to Mt. Sonnblick had the opportunity to pick up pollution from sources near the ground. In terms of fact, the earlier trajectories for 28 April 1997, 0:00 UTC to 30 April 1997, 0:00 UTC show surface contact at the Atlantic ocean; the later trajectories for 30 April 1997, 12:00 UTC, and 1 May 1997, 0:00 UTC show surface contact at continental areas in northern Europe where industrial emissions are likely.

The lack of a simple correlation of the snow-aerosol ${ }^{14} \mathrm{C}$ with the backward trajectories points of (land, ocean) contact may seem surprising. A simplistic interpretation may be misleading, however, because of 1) lacking information on the surface aerosol ${ }^{14} \mathrm{C}$ at the particular points and times of contact, 2) imperfections in backward trajectories models and input meteorological data, particularly for extended paths and time intervals, 3) the disjoint relation between air mass history and snow mass formation altitude and transport, and 4) the observed differences in organic aerosol carbon composition of simultaneously sampled air and snow (Gröllert et al. 1996). Although significant ${ }^{14} \mathrm{C}$ variations were observed, it is clear from Figure 4 that the aerosol carbon contained in all five snow episodes was predominantly biogenic.

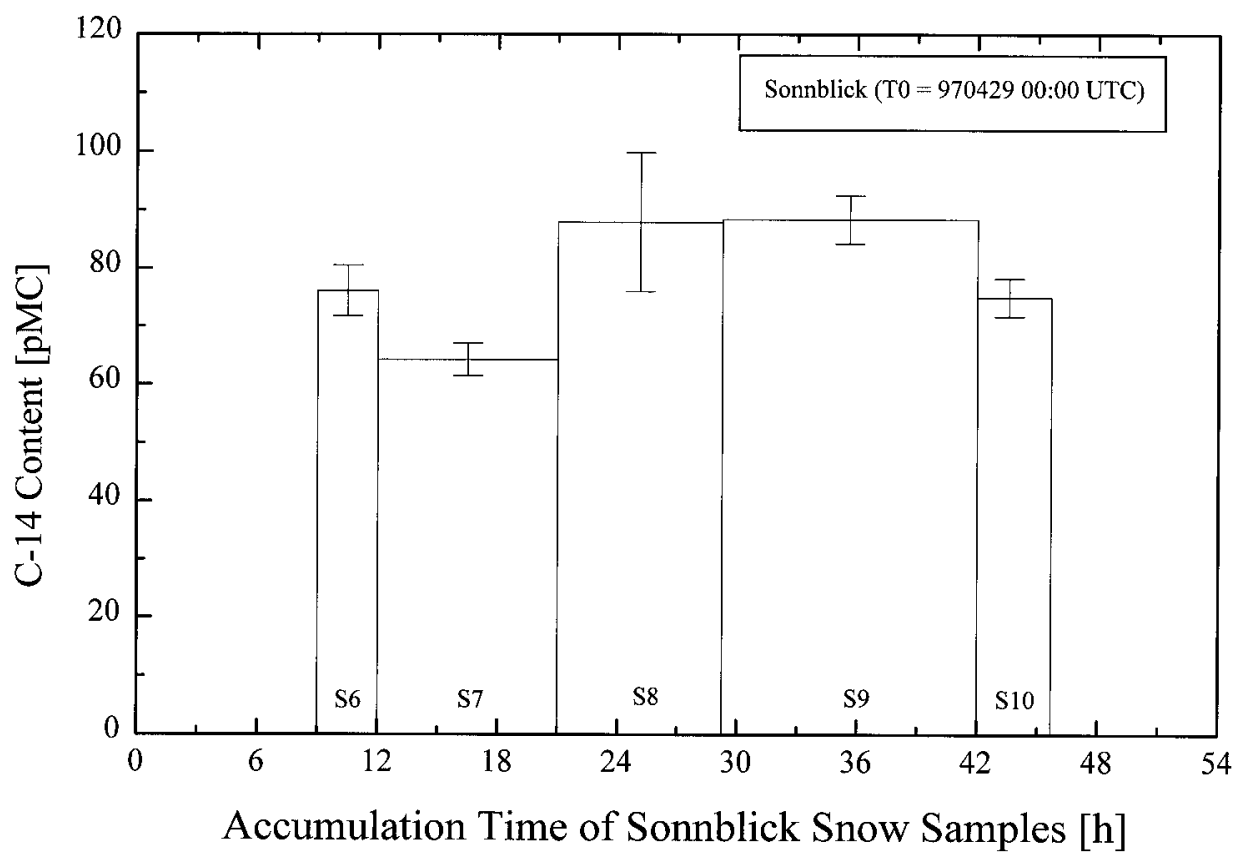

Figure $4{ }^{14} \mathrm{C}$ results of the carbonaceous snow samples collected at the high altitude research station Mt. Sonnblick in April 1997 


\section{CONCLUSION}

In this paper, we demonstrated that it is possible to measure the ${ }^{14} \mathrm{C}$ content of below $100 \mu \mathrm{g}$ carbon samples with AMS at VERA. As result carbonaceous aerosols extracted from snow at the high-altitude research station Mt. Sonnblick in the Eastern Alps, where little carbonaceous material accumulates, can be studied. The ${ }^{14} \mathrm{C}$ content of the aerosols is not simply correlated with the surface contact points of the corresponding air mass trajectories. Such a behavior is, however, expected for a background site at the mid tropospheric level (see e.g. Tscherwenka et al. 1998). The result of 64\% biogenic carbon in the filterable (water insoluble) part of the background aerosol at the 3-km level over Europe is indicative of the presence and dominance of biogenic polymeric material. Since the number of samples was quite limited in this study it would be very desirable to perform ${ }^{14} \mathrm{C}$ investigations in high Alpine aerosols 1) during different seasons, and 2) including the water soluble part.

\section{ACKNOWLEDGMENTS}

Snow sampling was part of Project 10328-CHE of the Austrian Science Foundation. We are grateful to Dipl-Ing Michael Mandl and Dr August Kaiser (Zentralanstalt für Meteorologie und Geodynamik, Vienna, Austria) for providing the 96-hr backward trajectories of Mt. Sonnblick.

\section{REFERENCES}

Chylek P, Srivastava V. 1987. Aerosol and graphitic carbon content of snow. Journal of Geophysical Research 92:9801-9.

Cooke WF, Wilson JJN. 1996. A global black carbon aerosol model Journal of Geophysical Research 101: 19395-409.

Currie LA, Benner BA Jr., Klouda GA, Conny JM, Dibbs JE. 1996. Tracking biomass burning aerosol: From the combustion laboratory to Summit, Greenland. Radiocarbon 38(1):20.

Currie LA, Dibb JE, Klouda GA, Benner BA, Conny JM, Biegalski SR, Klinedinst DB, Cahoon DC, Hsu NC. 1998. The pursuit of isotopic and molecular fire tracers in the polar atmosphere and cryosphere. Radiocarbon 40(1):381-90.

Gröllert C, Kasper A, Puxbaum H. 1997. Organic compounds in high Alpine snow. International Journal of Environmental Analytical Chemistry 67:213-22.

Hitzenberger R, Berner A, Giebl H, Kromp R, Larson SM, Rouc A, Koch A, Marischka S, Puxbaum H. 1999. Contribution of carbonaceous material to cloud condensation nuclei concentrations in European background (Mt. Sonnblick) and urban (Vienna) aerosols Atmospheric Environment 33:2647-59.

Kunit M, Puxbaum H. 1996. Enzymatic determination of the cellulose content of atmospheric aerosols. Atmospheric Environment 30:1233-6.

Kutschera W, Collon P, Friedmann H, Golser R, Hille P, Priller A, Rom W, Steier P, Tagesen S, Wallner A, Wild E, Winkler G. 1997. VERA: a new AMS facility in Vienna. Nuclear Instruments and Methods in Physics Research B123:47-50.

Lavanchy VMH, Gäggeler HW, Schotterer U, Schwikowski M, Baltensperger U. 1999. Historical record of carbonaceous particle concentrations from a European high-alpine glacier (Colle Gnifetti, Switzerland). Journal of Geophysical Research 104(D17): 27227-36.

Levin I, Graul R, Trivett NBA. 1995. Long-term observations of atmospheric $\mathrm{CO}_{2}$ and carbon isotopes at continental sites in Germany. Tellus 47B:23-34.

Priller A, Golser R, Hille P, Kutschera W, Rom W, Steier P, Wallner A, Wild E. 1997. First performance tests of VERA. Nuclear Instruments and Methods in Physics Research B123:193-8.

Rom W, Golser R, Kutschera W, Priller A, Steier P, Wild E. 1998. Systematic investigations of ${ }^{14} \mathrm{C}$ measurements at the Vienna Environmental Research Accelerator. Radiocarbon 40(1):255-63.

Rom W, Brenninkmeijer CAM, Bräunlich M, Golser R, Mandl M, Kaiser A, Kutschera W, Priller A, Puchegger S, Röckmann Th, Steier P. 1999. The "CO-OHEurope" project and measurements of ${ }^{14} \mathrm{C}$ monoxide concentrations in air from the high-altitude observatory Sonnblick (3106 m) in the Austrian Alps. Proceedings of the International Workshop on Frontiers in Accelerator Mass Spectrometry. National Institute for Environmental Studies, Tsukuba, Japan, 6-8 January 1999. p 228-43.

Saxena P, Hildemann LM. 1996. Water-soluble organics in atmospheric particles: a critical review of the literature and application of thermodynamics to identify candidate compounds Journal of Atmospheric Chemistry 24:57-109.

Stuiver M, Polach HA. 1977. Discussion: reporting of ${ }^{14}$ C data. Radiocarbon 19(3):355-63.

Tscherwenka W, Seibert P, Kasper A, Puxbaum H. 1998. On-line measurements of sulfur-dioxide at the $3 \mathrm{~km}$ 
level over central Europe (Sonnblick Observatory, Austria) and statistical trajectory source analysis. Atmospheric Environment 32:3941-52.

Verkouteren RM, Klinedinst DB, Currie LA. 1997. Ironmanganese system for preparation of radiocarbon AMS targets: Characterization of procedural chemical-isotopic blanks and fractionation Radiocarbon 39(3):269-83.

Weissenbök R, Biegalski SR, Currie LA, Klinedinst DB,
Golser R, Klouda GA, Kutschera W, Priller A, Rom W, Steier P, Wild E. 1998. ${ }^{14} \mathrm{C}$ measurements of submilligram carbon samples from aerosols Radiocarbon 40(1):265-72.

Wild E, Golser R, Hille P, Kutschera W, Priller A, Puchegger S, Rom W, Steier P, Vycudilik W. 1998. First ${ }^{14} \mathrm{C}$ results from archaeological and forensic studies at the Vienna Environmental Research Accelerator. Radiocarbon 40(1):273-81. 